\title{
Svitlana Humeniuk*
}

Narodowy Uniwersytet Gospodarki Wodnej i Zarządzania Zasobami Naturalnymi w Równym (Ukraina)

\section{Aspekty historyczno-filozoficzne stosunków ukraińsko-polskich przełomu XVI/XVII wieku}

\section{Streszczenie:}

Artykuł zawiera analizę historyczno-filozoficznych stosunków ukraińskopolskich przełomu XVI/XVII wieku. Autorka bada portret ówczesnych, środkowoeuropejskich możnowładców i myślicieli wyznania rzymskokatolickiego, w tym matematyka Jana Latosza (ok. 1539-ok. 1608), poetę Szymona Pękalę (ok. 1567-1616), kanclerza Lwa Sapiehę(1557-1633)i pisarza Jana Szczęsnego-Herburta (1567-1616), którzy nie tracąc własnych przekonań religijnych, zakorzenionych w chrześcijaństwie rytu zachodniego, obrali tolerancyjną postawę wobec oponentów z obozu prawosławnego. Autorka tekstu rozpatruje pojęcie tolerancyjności i jego specyfikę w okresie odrodzeniowych poszukiwań światopoglądowych: teocentrycznych i antropocentrycznych.

Słowa-klucze: tolerancyjność religijna, ośrodek ostrogski, katolicyzm, prawosławie.

Svitlana Humeniuk - doktor filozofii oraz docent w Katedrze Ukrainoznawstwa Narodowego Uniwersytetu Gospodarki Wodnej i Zarządzania Zasobami Naturalnymi w Równym na Ukrainie. 


\section{Historical and philosophical aspects of Ukrainian-Polish rela- tions at the turn of the $16^{\text {th }}$ and $17^{\text {th }}$ centuries}

\section{Summary:}

The article aims to analyse historical and philosophical UkrainianPolish relations at the turn of the $16^{\text {th }}$ and $17^{\text {th }}$ centuries. It depicts a portrait of the then, Roman Catholic Mid-European magnates and thinkers, including a mathematician Jan Latosz (ca. 1539-ca. 1608), a poet Szymon Pękala (ca. 1567-1616), a chancellor Lew Sapieha (1557-1633) and a writer Jan Szczęsny-Herburt (1567-1616), who, sticking to their religious beliefs rooted in Western Christianity, were as well tolerant towards opponents from the Orthodox denomination. The author analyses the notion of tolerance and its specifics in the period of Renaissance philosophical searches: both theocentric and anthropocentric.

Key words: religious tolerance, Ostrog centre, Roman Catholicism, Orthodoxy.

Stosunki ukraińsko-polskie, opisane przez współczesnych badaczy historii, literatury i filozofii - w ciągu wielu stuleci sąsiadowania ze sobą obu tych wschodnioeuropejskich narodów - miały dużo interesujących, pouczających, a czasem wręcz dramatycznych chwil. Analizując je, warto między innymi wprowadzić do naszych rozważań wątek historyczny, pamiętając jednocześnie, że wiele konfliktów w dziejach świata wynikało bezpośrednio z braku czyjejś tolerancyji religijnej. Wyzbycie się wzajemnych roszczeń i uprzedzeń konfesyjno-światopoglądowych może więc pomóc w znalezieniu wspólnej płaszczyzny dialogu Polski z Ukrainą, zapewnić ich dalsze współistnienie, wolne od niepotrzebnych sporów, a także - umożliwić im ciągłą kooperację w wymiarze kulturowym. 
Celem niniejszego badania jest szeroka analiza retrospektywna źródeł tolerancyjności religijnej na gruncie stosunków ukraińsko-polskich przełomu XVI/XVII wieku.

\section{Stan badań}

Stosunki ukraińsko-polskie zostały najpełniej opisane w wielotomowych pracach historiozoficznych urodzonego na Chełmszczyźnie Mychajły Hruszewskiego. Wśród współczesnych studiów naukowych podejmujących interesujący nas tutaj temat, najbardziej szczegółowe zdają się badania Wołodymyra Litwinowa, zawarte w jego tomie zatytułowanym Ruś Katolicka, jak również cały szereg publikacji Łarysy Dowhy, Petra Kraluka, Natalii Jakowenko. Ostatnia z wymienionych autorów skonstatowała, że „[...] pod koniec XVI wieku w życiu religijnym pojawia się różnorodność wyznań i rozbrat, który jej towarzyszy, a tworzą się za to dwa prądy przeciwne «ruskiej pobożności»"1.

Wśród polskich badaczy znanych na Ukrainie wymienimy przynajmniej: Władysława Tomkiewicza [Wołyń $w$ Koronie (1569-1795)]², Piotra Wawrzeniuka [Social Disciplining and Social Control in the L'viv diocese during the Episcopate of Iosyf Shumlians'kyi in the European context $]^{3}$ oraz Kazimierza Chodynickiego [Z dziejów prawosławia na Wotyniu (992-1596) ]4.

Spośród współczesnych uczonych i myślicieli warto jeszcze wspomnieć o Marku Melniuku [Polityczno-społeczny wymiar myśli i działalności Piotra Mohyty (1596-1647) jako problem badawczy] 5 .

1 N. Yakovenko, Paralelnyj svit: (doslidzh. $z$ istoriyi uyavlen' ta idej $v$ Ukrayini XVI-XVII st.), „Krytyka” 2002, s. 416.

2 W. Tomkiewicz, Wołyń w Koronie (1569-1795), „Rocznik Wołynski” 1931, t. 1, s. 25-67.

3 P. Wawrzeniuk, Social Disciplining and Social Control in the Lviv diocese during the Episcopate of Iosyf Shumlianskyi in the European context, Україна XVII cmoлimms: суспільство, філософія, культура: зб. наук. Пр, ред. М. Попович, К. 2005, С. 347-367.

4 K. Chodynicki, Z dziejow prawosławia na Wołyniu (992-1596), „Rocznik Wołyński" 1937 , t. 5/6, s. 53-106.

5 M. Melniuk, Polityczno-społeczny wymiar myśli $i$ działalności Piotra Mohyły (1596-1647) jako problem badawczy „Хроніка” 2000, № 39/40: Україна: філософський спадок століть, С. 207-226. 


\section{(Nie)tolerancja}

Należy podkreślić, że przełom XVI/XVII wieku był czasem ambitnych planów różnej maści społeczno-politycznych adwersarzy. To również okres nie do końca przemyślanych, gorączkowych prób porozumienia, wzajemnych rozczarowań i zarzutów. Ta nader trudna epoka swoistego ugruntowywania się geopolitycznego naszych narodów nie nabrałaby jednocześnie swego wyrazistego kształtu bez przedstawicieli kultury obu z wymienionych nacji. Oni to właśnie, nie niszcząc wielowiekowych tradycji własnych narodów, potrafili dobrotliwie, jak i tolerancyjnie, zachowując przy tym ludzką godność, stanąć w obronie swoich przekonań, szanując zarazem odmienne zdanie oponentów.

Różnice wyznaniowe w ówczesnej Europie były, jak wiadomo, często źródłem odmienności w sposobach traktowania przez jej mieszkańców nowożytnej filozofii. Model epistemologiczny [vide scholastyka świętego Tomasza z Akwinu (1225-1274) oparta na logice i wiedzy zewnętrznej] towarzyszył przeważnie zachodniemu nurtowi chrześcijaństwa, z kolei z wariantu sofistycznego korzystali częściej przedstawiciele świata chrześcijańskiego na Wschodzie. To odegrało decydującą rolę w procesie kształtowania się kultur naszych narodów, choć zrodziło wiele wzajemnych nieporozumień i prowadziło niejednokrotnie do zderzenia przeciwnych interesów.

Naszym celem badawczym pozostaje jednak wyszukanie przykładów takich zachowań przedstawicieli kultury staropolskiej, które by gruntownie udowodniły, że można było w owym czasie prowadzić swobodnie międzykulturowy dialog, szanując przy tym poglądy oponenta.

\section{Religia, historia i edukacja}

Warto nadmienić, że sfera duchowo-światopoglądowa na Ukrainie przełomu XVI/XVII wieku nie była w każdym calu ideologicznie jednoznaczna. Jednak, według historyków, niemal każdy Ukrainiec określał swoją przynależność narodową przez pryzmat prawosławia. Hruszewski zaznacza na przykład, że tylko ten, kto miał wyznanie „ruskie”, czyli prawosławne, uważał się w pełni za Rusina. Katolików na tych ziemiach 
uznawano za Polaków. Mamy tu więc do czynienia z literalnym utożsamieniem czyjejś konfesji z konkretną przynależnością narodową. To było jednym z głównych czynników jednoczących naród ukraiński z prawosławiem ${ }^{6}$.

Szczególnie trudny do analizy historyczno-filozoficznej pozostaje okres przełomu XVI/XVII wieku w Europie Wschodniej. Sytuacja religijna na terenie Ukrainy była wówczas niemal zbieżna z tamtejszym życiem politycznym. Oba te czynniki wpływały wprawdzie na ówczesną kulturę ukraińską, choć nie osłabiały w żaden sposób jej dążeń do dalszego rozwoju.

Szkolnictwo i oświata duchowa były na terenach obecnej Ukrainy doby XV-XVI wieku - po dokonanym przez Turków podboju całego południowo-wschodniego świata prawosławnego - w nienajlepszym stanie. Pierwsze ukraińskie książki, drukowane na potrzeby miejscowej ludności w języku cerkiewnosłowiańskim, tak zwanych „pięć ksiąg słowiańskoruskich”, to: Szestodnew («Шестодневъ»), Czasosłow («Часословъ»), Triod postnaja («Тріодь постная»), Triod cwietnaja («Тріодь цвђтная») oraz Psałtir sliedowannaja («Псалтирь слђдованная»). Zostały one wydrukowane w Krakowie w 1491 roku przez Niemca Szwajpolta Fiola (?-ok. 1525).

Przez długi czas na ziemiach ukraińskich istniały tylko szkoły podstawowe przy cerkwiach i klasztorach. Wykształcenie wyższe zdobywano więc samodzielnie, albo kształcąc się w szkołach zachodnioeuropejskich. W 1565 roku Kościół rzymskokatolicki rozpoczął własną działalność kontrreformacyjną, za sprawą której na terenach Rzeczypospolitej pojawili się aktywiści jezuiccy. W tak trudnych warunkach społeczno-dziejowych ukształtował się de facto duży ruch kulturalno-oświatowy w Ostrogu na Wołyniu (zob. Akademia Ostrogska). Większość z działaczy ostrogskich stała jednak na straży prawosławia i miała poglądy wyraźnie ortodoksyjne.

Organizacją tak potężnego centrum kulturowego zajął się nie kto inny, jak książę Konstanty Wasyl Ostrogski (ok. 1524/1525-1608). Spotykał się on z częstą krytyką swojej osoby, między innymi za „brak ochoty do wypowiedzi ostrej i bez ogłady” i chęć pozostawania „przez całe życie

6 M. S. Grushevskyj, Istoriya Ukrayiny-Rusy` v 11 t., 12 kn., Kiïv: Nauk. dumka, 1995, T. 6, s. 667. 
w tle współczesnej mu walki religijno-narodowej”. Twierdzono również, że „niczym monarcha znajduje dla każdego miłe słowo”, mimo swej niedostatecznie „wybitnej indywidualności”. Uważano go jednak za „naczelnika prawosławia”. Petro Sauh podkreślał wyjątkową mądrość księcia, odziedziczoną przez niego po świętym Fiodorze Ostrogskim (1360-1446), który „ukierunkował go na tradycje Rusi Kijowskiej”.

\section{Wybitne postaci polsko-ukraińskiej kultury}

Konstantemu Ostrogskiemu udało się też przyłączyć do ruchu społeczno-oświatowego na Wołyniu wielu cudzoziemców pracujących nie mniej owocnie i ofiarnie niż on dla dobra kultury ukraińskiej. Wśród nich znaleźli się między innymi: Grecy Cyryl Lukaris (1572-1638), przyszły patriarcha Konstantynopola; Nicefor Kantakuzen (ok. 1540-1599), męczennik i święty Kościoła prawosławnego; archimandryta Dionizy Rallis Paleolog (1534-1620); Rosjanin Iwan Fiedorow (1520-1583); Białorusin Andrzej Rymsza (ok. 1550-ok. 1593) i Polak Jan Latosz (ok. 1539-ok. 1608), absolwent Uniwersytetu Jagiellońskiego, profesor matematyki, astronom i filozof, który wskazał między innymi na błędy w reformie kościelnego kalendarza.

Jan Latosz był synem krakowskiego mieszczanina. Swoją edukację uwieńczył formalnie dwuletnimi studiami w Padwie. Według wspomnień Ihora Mycko, w 1582 roku otrzymał Latosz na tamtejszym uniwersytecie tytuł doktora medycyny, a rok później „zaczął wypowiadać się przeciwko nowemu [...] kalendarzowi gregoriańskiemu, wskutek czego doznał prześladowań ze strony jezuitów i hierarchów kościelnych"9. Polski badacz Leszek Hajdukiewicz wspominał, że od 1594 roku Latosz dedykował swoje prognostyki rodzinie Ostrogskich. Całkiem możliwe, że był on również wykładowcą grecko-łacińsko-słowiańskiej Akademii Ostrogskiej. Wszak przeprowadził się w 1596 roku do Ostroga, gdzie

\footnotetext{
Tamże.

8 P. Sauh, Knyaz`Vasy`l-Kostyanty`n Ostroz`ky`j, Rivne: Voly`n. oberegy`, 2002, s. 224.

9 I. Z. Myczko, Ostroz`ka slov'yano-greko-laty`ns'ka akademiya (1576-1636), Kiïv: Nauk. dumka, 1990, s. 190.
} 
w zamku, tuż obok uczelni, miał własne lokum. Ten znany i poważany w swojej epoce astronom włożył dużo wysiłku w ukształtowanie pierwszej wyższej szkoły typu grecko-słowiańskiego na Wołyniu.

Kolejną nieprzeciętną osobowością niniejszego okresu był również ukraińsko-polski poeta Szymon Pękala (z łac. Pekalides, ok. 1567-ok. 1616). To pisarz dworski Konstantego Ostrogskiego oraz autor najpopularniejszego w tym czasie poematu w języku łacińskim zatytułowanego Wojna Ostrogska (z łac. De bello Ostrogiano, 1600), w treści którego wychwalał on Konstantego i Janusza Ostrogskich (ok. 1554-1620). Litwinow uważa niniejszy utwór za jedną z najwybitniejszych ówczesnych prac historiograficznych o wyraźnym nacechowaniu humanistycznym ${ }^{10}$. Prowidencjalizm i fatalizm ustępują tu miejsca przed uwarunkowanymi historycznie czynami bohaterów, którzy poprzez własną uczciwość oraz odwagę próbują osiągnąć „,ziemską nieśmiertelność”. Według tegoż badacza, Pękala popierał monarchię dziedziczną w postaci ukraińskiego księstwa, na czele którego stałby „koronowany filozof”.

Za najbardziej interesujący fakt w stosunkach polsko-ukraińskich tego dramatycznego okresu można chyba uznać, zachowane do dziś, teksty polsko-ukraińskiego pisarza Jana Szczęsnego-Herburta (1567-1616), który był zadeklarowanym katolikiem. Występował on jednak jako obrońca „ruskiej wiary” - prawosławia. Wypowiadał się zdecydowanie przeciwko wszelkiemu zniewalaniu narodu ukraińskiego, przypominając jednocześnie Polakom o tym, że ,żaden umysł, żadna przemoc nie może dobić się tego, by Rusi na Rusi nie pozostało. A co, gdyby ktoś zechciał, by Polaków zabrakło w Polsce?"11.

Szczęsny-Herburt stał się nawet założycielem prawosławnego klasztoru w Dobromilu. Jednocześnie nie popierał on decyzji unii brzeskiej (1596), której zwolennikiem był król Polski Zygmunt III Waza (1566-1632): „Gdy szukają rzeczy duchowych, czemu nie sposobem duchowym?... Ale zbrodnią cerkwie brać, pozwami do sądów wzywać, łapać popów, wypędzać mnichów - to wszystko się nie godzi z wolą i nauką Zbawicie-

10 V. Lytvynov, Katoly`cz'ka Rus` : ist. - filosof. nary`s, Kiïv: Ukr. centr duxov. kultury, 2005, s. 276.

11 Tamże. 
la naszego. Raczej takie słowa można powiedzieć: «Szukasz swego zysku, nie Chrystusowego»"12. Szczęsny-Herburt napisał między innymi wysoce patriotyczny utwór zatytułowany Zdanie o narodzie ruskim... (ok. 1611-1613).

Wymieńmy jeszcze kanclerza Lwa Sapiehę (1557-1633), który swoją drogę konfesyjną przebył przecież od prawosławia, przez kalwinizm aż do katolicyzmu. Krytykował on unickie prześladowania prawosławnych Rusinów w Polsce. Według polskich badaczy, Sapieha (urzędnik królewski i polityk) wspominał w liście do biskupa unickiego Jozafata Kuncewicza (ok. 1580-1623) z dnia 12 marca 1622 roku przede wszystkim, że: „[...] pełne sądy ziemskie, pełne rady miejskie, pełne ratusze, pełne kancelarie biskupskie pozwów, procesów, protestacji”"13.

Tak więc tło historyczne, na którym się rozgrywała działalność oświatowców ostrogskich, pozwala stwierdzić, że u źródeł konfrontacji społeczno-polityczno-religijnych stał wówczas problem wielkich rozbieżności między dwoma obozami polemistów - przeciwnikami i zwolennikami unii brzeskiej. I to właśnie stanowiło zaczyn ich nieustannych polemik. Wyjątkowość opisywanej sytuacji polega jednakże na tym, że wśród zgiełku konfesyjnych sporów znalazło się wtedy miejsce na działania koncyliacyjne.

\section{(Teo)antropocentryzm}

Pamiętajmy przede wszystkim, że w odróżnieniu od introwertyzmu jako cechy właściwej dla wschodnio-chrześcijańskiego teoantropocentryzmu, za pomocą którego tradycjonaliści usprawiedliwiają wyłącznie transcendentny wymiar aksjologiczny życia człowieka, ekstraweryzm zachodniochrześcijański, z którym właśnie toczy się niniejsza polemika, proponuje określone rozwiązania pragmatyczne. Od wieków kusiły one tradycjonalistów nagrodą etycznego utwierdzenia się człowieka „tu i teraz". To przede wszystkim hasło Leona Kreuzy-Rzewuskiego (ok.

12 Tamże.

13 V. Antonovych, Shho pry`nesla Ukrayini uniya: stan ukr. pravoslav. cerkvy vid polovy`ny`XVII do kincya XVIII st., Vinnipeg: Ekkleziya, 1991, s. 132. 
1569-1639): „starać się o ustanowienie, objaśnienie i pomnożenie praw i wolności naszych, tak duchownych jako i świeckich"14.

Chodzi tutaj więc o zadeklarowaną opiekę nad tradycjonalistami ze strony reprezentantów europejskiego paradygmatu antropocentrycznego, tak w zakresie rozszerzenia ich praw i wolności duchowych, jak i świeckich. Miało to być poniekąd, w mniemaniu reformatorów, nagrodac lub rekompensatą za zmianę własnych postaw światopoglądowych bądź swoistym kompromisem na drodze czyjegoś przyłączenia się do unii. Kreuza-Rzewuski podkreślał przy tym brak religijnego wzorca „greckiej duchowości” na terenach państwa polsko-litewskiego: „[...] w tym królestwie zadzierżeć nabożeństwa Greckiego w całości swej nie możemy, nie będąc w jedności z Kościołem Rzymskim"15.

Vitalij Szewczenko podkreśla - w swoich badaniach nowożytnych religii pod kątem idei tolerancji jako ewentualnej podstawy do zgody międzykonfesyjnej - że „,...] dialog doktryn ma znaczenie pierwszorzędne w kształtowaniu się oficjalnych wspólnot religijnych. Ponadto może stawać się on szczególnie ostry i napięty, ponieważ każda religia deklaruje charakter ogólnoświatowy oraz wyjątkowy potencjał własnego doświadczenia transcendentnego. Akceptacja równowartości i równoznaczności wszystkich «dróg do Boga» dla człowieka szczerze wierzącego jest zupełnie niemożliwa. To znaczy, że doktrynalna tolerancyjność międzywyznaniowa prowadzi do eklektyki religijno-światopoglądowej i zobojętnienia pozareligijnego, więc dialog tych obszarów może mieć tylko charakter konfrontacji"16. Religijni oponenci i tak obiorą siebie bowiem, prędzej czy później, za cel własnych działań misjonarskich.

Wśród wymienionych przykładów międzyreligijnych sporów i animozji istniały również postawy zgoła odmienne, bo wyważone i nienastawione na jałowe konfrontacje. Przecież matematyk Jan Latosz, poeta

14 L. Krevza, "Oborona uny`y», sochy`neny`e 1617 goda, [w:] Pamyatny 'ky`ly`teraturnoj polemy 'ky' pravoslavnux yuzhno-russov s protestantamy' $y^{\prime}$ 'aty 'no-uny' atamy $v$ YugoZapadnoj Rusy` za XVI y` XVII st., Kiïv 1914, T. 4, s. 266-298 (Arxy`vы Yugo-Zapadnoj Rossy`y`; ch. 1. ; t. 7).

15 Tamże.

16 V. Shevchenko, Ukrayina duxovna: Postati, podiyi, yavy`shha, Kï̈v: «Svit Znan`», 2008, s. 527. 
Szymon Pękala, kanclerz Lew Sapieha oraz pisarz Jan Szczęsny-Herburt nie dążyli wcale do scysji doktrynalnych z przedstawicielami wyznania wschodnio-chrześcijańskiego. A wszyscy oni byli ważnymi działaczami ówczesnej kultury i zadeklarowanymi katolikami. Swoją aktywność polityczno-pisarsko-oświatową wiedli w jednym z najbardziej dramatycznych okresów kształtowania się tożsamości ukraińskiej. Bronili prawa osób o wyznaniu prawosławnym do kultywowania „wiary swych ojców”. Dokładali też wszelkich starań na niwie publicznej do jak najrzetelniejszego prezentowania kultury ukraińskiej pod kątem jej wyjątkowości. Ich szlachetne czyny ilustrowały wysoki wzorzec ludzkiej godności i szlachetności w ekstremalnych warunkach polityczno-historyczno-kulturowych. Własną postawą świadczyli wyraźnie o tolerancyjności, szczególnie na tle (post)renesansowych poszukiwań światopoglądowych o zabarwieniu stricte teoantropocentrycznym.

Według igumena Wenjamina (Nowika), zajmującego się badaniem duchowego wymiaru tolerancyjności, prawdziwa wyrozumiałość, przewidująca kompromis $\mathrm{w}$ granicach humanizmu, nie ma nic wspólnego z rygorystycznością czy znieważaniem prawdy. Wręcz przeciwnie - wszelka tolerancyjność wykazuje szacunek wobec prawdy, która z kolei winna być pojmowana przez każdego zgodnie z jego własną wolą. Będąc w stosunku do siebie maksymalistą, należy wobec innych okazywać pełną estymę i empatię, gdyż bez tego tak zwane życie społeczne staje się zupełnie niemożliwe ${ }^{17}$.

\section{Wnioski}

Niniejsza analiza retrospektywna źródeł tolerancyjności religijnej w Europie Wschodniej na przełomie XVI/XVII wieku świadczy między innymi o tym, że wszelkie próby jej tam ustanowienia odbywały się wówczas w bardzo trudnych warunkach polityczno-społecznych. Mimo to wykazaliśmy na wielu przykładach jaskrawe wzorce prawdziwej tolerancyjności opartej na mądrym kompromisie.

17 V. Novy`k, Duxovnuj smusl tolerantnosty` (Tolerantnost`: sy`la y`ly slabost’?); http:// www.gumer.info/ bogoslov_Buks/Philos/Article/nov_tol.php [dostęp: 02.01.2019 r.]. 
Współczesne rozumienie powyższej problematyki (zgodnie z Deklaracja zasad tolerancyjności ${ }^{18}$ ) odnosi nas nie tylko do idei szacunku i akceptacji, mających na celu pomóc w zrozumieniu olbrzymiej ilości kultur obecnego świata, ale również wynika ze sposobów przejawania się ludzkiej indywidualności. Dążenie do kompromisu pozostaje bowiem moralnym obowiązkiem i niezbędnym politycznie prawem dzisiejszego człowieka.

Zaprezentowane tu postawy społeczno-etyczne zadeklarowanych katolików (vide matematyk Jan Latosz, poeta Szymon Pękala, kanclerz Lew Sapieha i pisarz Jan Szczęsny-Herburt), pokazują dobitnie, że nie zdradzając własnych przekonań religijnych, wyrosłych z zachodniego wzorca chrześcijaństwa, bardzo tolerancyjnie i z poszanowaniem traktowali własnych oponentów wyznających prawosławie. Możemy to zatem uważać za początkowy etap kształtowania się tolerancyjności religijnej w Europie Wschodniej przełomu XVI/XVII wieku.

\section{Perspektywy dalszych badań naukowych}

Współczesna epoka zdominowana przez procesy globalizacji zachęca nas między innymi do wnikliwszego niż dotychczas badania płaszczyzny filozoficznej ojczystej kultury duchowej, jak i do próby ponownej oceny dziedzictwa zachodniego modelu chrześcijaństwa w celu właściwej interpretacji nowożytnego dorobku myślowego Europy Wschodniej. W ten sposób tworzymy również portret moralny człowieka tamtych czasów.

18 Деларация принципов толерантности // http://www.un.org/ru/documents/ decl_conv/declarations/toleranc.shtml [dostęp: 17.01.2019 r.]. 
Svitlana Humeniuk, Aspekty historyczno-filozoficzne stosunków ukraińsko-polskich...

\section{Źródła}

Chodynicki Kazimierz, Z dziejów prawosławia na Wołyniu (992-1596), „Rocznik Wołyński" 1937, t. 5/6, s. 53-106.

Melniuk Marek, Polityczno-społeczny wymiar myśli i działalności Piotra Mohyły (1596-1647) jako problem badawczy, „Хроніка” 2000, № 39/40, Україна: філософський спадок століть, с. 207-226.

Tomkiewicz Władysław, Wołyń w Koronie (1569-1795), „Rocznik Wołynski” 1931, t. 1 , s. 25-67.

Wawrzeniuk Piotr, Social Disciplining and Social Control in the L'viv diocese during the Episcopate of losyf Shumlians'kyi in the European context, Україна XVII століття: суспільство, філософія, культура: зб. наук. пр., ред. Мирослав Володимирович Попович, Київ 2005, с. 347-367.

Антонович Володимир, Що принесла Україні унія : стан укр. православ. церкви від половини XVII до кінця XVIII ст, Вид. 2-ге, з доповн. Вінніпег: Екклезія, 1991, 132 с.

Деларация принципов толерантности. Protokół dostępu: www.un.org/ru/ documents/decl_conv/declarations/toleranc.shtml [dostęp: 17.01.2019 r.].

Грушевський Михайло Сергійович, Історія України-Руси: в 11 т., 12 кн., t. 6, Київ: Наук. думка, 1995, 667 с.

Кревза Лев, «Оборона унии», сочинение 1617 года. Памятники литературной полемики православных южно-руссов с протестантами и латино-униатами в Юго-Западной Руси за XVI и XVII ст., t. 4., Киев 1914, s. 266-298.

Литвинов Володимир, «Католицька Русь»: іст.-фрілософ. нарис., Київ: Укр. центр духов. культури, 2005, 276 с.

Мицько Ігор Зіновійович, Острозька слов'яно-греко-латинська академія (1576-1636), Київ: Наук. думка, 1990, 190 с.

Новик Вениамин, Духовный смысл толерантности (Толерантность: сила или слабость?). Protokół dostępu: http://www.gumer.info/bogoslov_Buks/Philos/Article/nov_tol.php [dostęp: 02.01.2019 r.].

Саух Петро Юрійович, Князь Василь-Костянтин Острозький, Рівне. Волин. Обереги, 2002, s. 224.

Шевченко Віталій Володимирович, Україна духовна: Постаті, події, явища, Київ: «Світ Знань», 2008, 527 с. 
Яковенко Наталія, Паралельний світ : (дослідж. з історії уявлень та ідей в Україні XVI-XVII ст.), Київ: Критика, 2002, 416 с.

\section{Bibliografia}

Antonovych Volodimir, Shcho prynesla Ukraini uniia : stan ukr. pravoslav. tserkvy vid polovyny XVII do kintsia XVIII st., Vyd. 2-he, z dopovn. Vinnipeh: Ekkleziia, 1991, 132 s.

Chodynicki Kazimierz, Z dziejów prawosławia na Wołyniu (992-1596), „Rocznik Wołyński" 1937, t. 5/6, s. 53-106.

Delaratsyia pryntsypov tolerantnosty. Protokół dostępu: www.un.org/ru/ documents/decl_conv/declarations/toleranc.shtml [dostęp: 17.01.2019 r.].

Hrushevskyi Mikhajjlo Sergijjovich, Istoriia Ukrainy-Rusy: v 11 t., 12 kn., t. 6, Kiïv: Nauk. dumka, 1995, 667 s.

Krevza Lev, «Oborona unii», sochinenie 1617 hoda. Pamiatniki lyteraturnoi polemiki pravoslavnykh yuzhno-russov s protestantami i latino-uniatami v Yuho-Zapadnoi Rusi za XVI y XVII st., t. 4, Kiev 1914, s. 266-298.

Lytvynov Volodimir, «Katolytska Rus»: ist.filosof. narys., Kiïv: Ukr. tsentr dukhov. kultury, 2005, $276 \mathrm{s.}$

Melniuk Marek, Polityczno-społeczny wymiar myśli i działalności Piotra Mohyły (1596-1647) jako problem badawczy, „Khronika” 2000, № 39/40, Ukraina: filosofskyi spadok stolit, c. 207-226.

Mytsko Igor Zinovijjovich, Ostrozka sloviano-hreko-latynska akademiia (15761636), Kiïv: Nauk. dumka, 1990, 190 s.

Novyk Veniamin, Dukhovnыi smыsl tolerantnosty (Tolerantnost: syla ili slabost?).

Protokół dostępu: http://www.gumer.info/bogoslov_Buks/Philos/Article/nov_tol. php [dostęp: 02.01.2019 r.].

Saukh Petro Jurijjovich, Kniaz Vasyl-Kostiantyn Ostrozkyi, Rivne. Volyn. Oberehy, 2002, s. 224.

Shevchenko Vitalijj Volodimirovich, Ukraina dukhovna: Postati, podii, yavyshcha, Kiïv: «Svit Znan», 2008, 527 s.

Tomkiewicz Władysław, Wołyń w Koronie (1569-1795), „Rocznik Wołynski” 1931, t. 1, s. 25-67.

Wawrzeniuk Piotr, Social Disciplining and Social Control in the Lviv diocese during the Episcopate of Iosyf Shumlianskyi in the European context, Ukraina XVII sto- 
Svitlana Humeniuk, Aspekty historyczno-filozoficzne stosunków ukraińsko-polskich...

littia: suspilstvo, filosofiia, kultura : zb. nauk. pr., red. Miroslav Volodimirovich Popovych, Kiïv 2005, s. 347-367.

Yakovenko Natalija, Paralelnyi svit : (doslidzh. z istorii uiavlen ta idei v Ukraini KhVIKhVII st.), Kiïv: Krytyka, 2002, 416 s. 